https://doi.org/10.31-26/pragya.v7i1.35255

\title{
Population Dynamics in Nepal Over 100 Years
}

Thapa Keshav

\begin{abstract}
Population dynamics is the branch of life sciences that studies short-term and long-term changes in the size and age composition of populations, and the biological and environmental processes influencing those changes. The main aim of this article is to analyze the size, distribution, change, growth, trend, pattern and other over all status of population of Nepal of last hundred years (1911 - 2011). Secondary information obtained by author from authentic and reliabledifferent sources and rearranged, re-calculated, re-tabulated and analyzed and make meaningful and sensible of them. Number of population are almost 5 fold increased during the $(1930-2011) 80$ years period of time. The population growth rate and doubling times are fluctuation. CDR, CBR, IMR, CMR, MMR are decreasing as increasing of the socio economic development in Nepal. Life expectancy, literacy rate, active age population rate are increasing. The identification of the caste/ethnic groups are rapidly increased, only 60 caste/ethnic groups were identified in 1991, it has increased and reached 100 caste/ethnic groups in 2001 and 125 caste/ethnic groups in 2011 census. Population dependency ratio of child is decreasing and increasing of the old age dependency ratio. If old age population growth rate will remaining the same the old age dependency ratio will be increased by 3 fold till 2050. Almost 60 percent populations are living in urban duelers. The CBS of Nepal is going to conduct the census in beginning of 2078 BS and expected total population to be more than 31.5 millions.
\end{abstract}

Keywords: Dynamic, Population, Census, CBR, CDR, Migration.

\section{Introduction}

Population dynamics is the branch of life sciences that studies short-term and long-term changes in the size and age composition of populations, and the biological and environmental processes influencing those changes. Population dynamics deals with the way populations are affected by birth and death rates, and by immigration and emigration, and studies topics such as ageing populations or population decline.

Population dynamics has traditionally been the dominant branch of mathematical biology, which has a history of more than 210 years, although more recently the scope of mathematical biology has greatly expanded. The first principle of population dynamics is widely regarded as the exponential law of Malthus, as modeled by the Malthusian growth model. The early period was dominated by demographic studies such as the work of Benjamin Gompertz and Pierre François Verhulst in the early 19th century, who refined and adjusted the Malthusian demographic model. 
In Nepal, the size of population was decreased from 1911 to 1931 then after it is continue increasing and population size became more than 5 fold during 80 years period ( 1930 to 2011 - 5532574 in 1930 and 26494504 in 2011). Likewise, the population growth rate is fluctuation, TFR, CBR, CDR, ty rate, are decreasing. Old age population are increasing, the proportion of below 15 years age population is decreasing (40 percent in 2001 and 35 percent in 2011) The tendency of migration from rural hill and mountain to urban and Terai regions is increasing. More than 6 millions young active age populations are immigrated for foreign employment. The Identification of caste/ethnic groups are increasing 100 caste ethnic groups were in 2001 and 125 in 2011. However, people are changing their religions simply poverty. The CBS of Nepal is going to conduct the census in beginning of 2078 BS and expecting total population to be more than 31.5 millions and increases the caste/ethnic groups. The main aim of this article is to analyze the size, distribution, change, growth, trend, pattern and otherover all status of populationof Nepal since last hundred years (1911 - 2011) and expecting the total population by 2078 census.

This article is based on the information of population dimensionof Nepal. Author has not collected and analyzed other information/ data besides the population dimension of Nepal. Author has collected secondary information from different sources, analyzed and repeated them carefully with his own way. The sources of information has been clearly mentioned and also given the references too. Author has prepared this article maintaining the academic ethics and values.

\section{Methods and Materials}

This article is based on secondary and quantitative information with cross sectional methods. The information are interpreted with inductive approach.However, information / data are obtained by author from the different authentic and reliable secondary sources and those are re-arranged, re-tabulated, re-calculated and analyzed and make sensible as far as meaningful so readers could understand the trends, patters and situation of population dynamic of theNepal with easy and simple way. However, author became very conscious during selection and analyzing the information to minimize the errors.

\section{Result and Discussion}

\section{Years of Population Dynamics in Nepal}

Population of Nepal was decreased from1911 to 1930, then after it is gradually increased. The sex, since 1911 to 2011, is in fluctuation. The population doubling time is determined by the population annual growth rate so it is also the fluctuation as fluctuating in the population growth rate. As recent census the female population is more in comparing to the 
male population. The population density is increasing as increased the size of national population. Size of population is increasing in Terai and decreasing in Hill and Mountain regions. The urban population was very nominal level in 1911 but it has increased and reached 17 percent in 2011 and it has reached 59 percent in 2017 as increased the urban areas 58 to 293. The life expectancy, level of education of male and female are increasing. The total fertility rate is decreasing and almost reaching in replacement level (2.3: 2016 NDHS). The maternal mortality rate (239:100000), infant mortality rate (32:1000), child mortality (39:1000) are decreasing. In 2011 census, more than 1.9 millions population is absent. Around 7 millions population is out of country for different purpose. As Nepal government, Department of Foreign migration, every day 1600 economic active population are migrating for foreign labour works and this rate is increasing. However, the population is increased almost more than 5 folds during this 100 years.

Table 1. One Hundred Years of population changes (1911-2011)

\begin{tabular}{|c|c|c|c|c|c|c|c|c|}
\hline \multirow{2}{*}{$\begin{array}{r}\text { Cens } \\
\text { us } \\
\text { year }\end{array}$} & \multicolumn{4}{|c|}{ Population } & \multicolumn{2}{|c|}{$\begin{array}{c}\text { Population change } \\
\text { between census }\end{array}$} & \multirow{2}{*}{$\begin{array}{r}\text { Growt } \\
\text { h over } \\
1911 \\
\text { (perce } \\
\text { nt) }\end{array}$} & \multirow{2}{*}{$\begin{array}{l}\text { Annu } \\
\text { al } \\
\text { growt } \\
\text { h rate }\end{array}$} \\
\hline & Total & Male & Female & $\begin{array}{r}\text { Sex } \\
\text { ratio }\end{array}$ & Number & $\begin{array}{r}\text { Perce } \\
\text { nt }\end{array}$ & & \\
\hline 1911 & $5,638,749$ & 2820220 & 2818529 & 100.1 & - & - & - & \\
\hline 1920 & $5,573,788$ & 2799074 & 2774714 & 100.9 & $\begin{array}{r}-\quad 649 \\
61\end{array}$ & -1.15 & -1.15 & -0.13 \\
\hline 1930 & $5,532,574$ & $\mathrm{na}$ & $\mathrm{na}$ & $\mathrm{na}$ & -41214 & -0.74 & -1.88 & -0.07 \\
\hline 1941 & $6,283,649$ & 3207709 & 3075940 & 104.3 & 751075 & 13.58 & 11.44 & 1.16 \\
\hline $\begin{array}{r}1952 \\
/ 54\end{array}$ & $8,256,625$ & 4050607 & 4184472 & 96.8 & 1972976 & 31.40 & 46.43 & 2.27 \\
\hline 1961 & $9,412,996$ & 4636033 & 4776963 & 97.0 & 1156371 & 14.01 & 66.93 & 1.64 \\
\hline 1971 & $11,555,983$ & 5817203 & 5738780 & 101.4 & 2142987 & 22.77 & 104.94 & 2.05 \\
\hline 1981 & $15,022,839$ & 7695336 & 7327123 & 105.0 & 3466856 & 30.00 & 166.42 & 2.62 \\
\hline 1991 & $18,491,097$ & 9220974 & 9270123 & 99.5 & 3468258 & 23.09 & 227.93 & 2.08 \\
\hline 2001 & $23,151,423$ & 11563921 & 11587502 & 99.8 & 4660326 & 25.20 & 310.58 & 2.25 \\
\hline 2011 & $26,494,504$ & 12849041 & 13645463 & 94.2 & 3343081 & 14.44 & 369.86 & 1.35 \\
\hline
\end{tabular}

Source: 1. Bastola, T.S., (2014)

(n a = not available) 
2. Bisht P.S and Joshi M.R., (2067).3.CBS, (2003). Population monographs of Nepal, Vol. I \&II

As table 1, total population was recorded 5638749 in 1911 and it was decreased continue until 1930 and reached 5532574. Then after continually increased and reached 26494504 in 2011 and that are increased more than 5 fold during around 80 years periods of time. While analyzed the number of male and female population, female population are more than male since 1991 census which means sex ratio is decreasing. The sex ratio was 105 in 1981 and 94.2 in 2011. The annual population growth rate is being fluctuation since 1941. But it is decreased from 2.25 percent in 2001 and 1.35 percent per annum in 2011.

Table 2: Population Doubling Time and Population Densityin Nepal 1911- 2011

\begin{tabular}{|l|c|c|}
\hline \multicolumn{1}{|c|}{ Census year } & Doubling time in years & Persons per. Sq.km \\
\hline 1911 & - & 38.31 \\
\hline 1920 & - & 37.87 \\
\hline 1930 & - & 37.59 \\
\hline 1941 & 60 & 42.69 \\
\hline $1952 / 54$ & 31 & 56.10 \\
\hline 1961 & 42 & 63.96 \\
\hline 1971 & 34 & 78.52 \\
\hline 1981 & 26 & 102.07 \\
\hline 1991 & 33 & 125.64 \\
\hline 2001 & 31 & 157.30 \\
\hline 2011 & 56 & 180.0 \\
\hline
\end{tabular}

Source: CBS 2001 Population monographs V.1, p3 table 1.1, 2011, Population Monographs, V. I .

Population doubling time depends on the population growth rate. The population growth rate of Nepal is fluctuation since beginning therefore, the population doubling time is also fluctuation. As 1941 census, population doubling times was 60 years and it has almost decreased by half (31 years) in 2052/54 and again increased and reached 42 years in 1961, and decreased and reached in 43 years in 1971 and decreased in 1981 and increased in 1991 and 31 years in 2001. But increased and reached 56 years in 2011. While analyzed the population density, the population density was only 42.69 in 1941 and it is increasing as increased the population size and it has reached 180 in 2011 (table 2) 
Table 3: Population Distribution by Ecological zone (1952/54 -2011)

\begin{tabular}{|l|l|l|l|l|}
\hline Cesus year & Total population & \multicolumn{1}{|c|}{ Mountain (\%) } & Hill (\%) & \multicolumn{1}{|c|}{ Terai (\%) } \\
\hline $1952 / 54$ & 8256625 & - & - & 35.2 \\
\hline 1961 & 9412996 & - & - & 36.4 \\
\hline 1971 & 11555983 & 9.9 & 52.5 & 37.6 \\
\hline 1981 & 15022839 & 8.7 & 47.7 & 43.6 \\
\hline 1991 & 18491097 & 7.8 & 45.5 & 46.7 \\
\hline 2001 & 23151423 & 7.3 & 44.3 & 48.4 \\
\hline 2011 & 26494504 & 6.7 & 43 & 50.3 \\
\hline
\end{tabular}

Source: CBS 2003 Population monographs V.1, and population monographs 2014, V.I

As table 3, the size of population is gradually decreasing in mountain and hilly regions and increasing in Terai regions. In 1971, almost 10 percent population was residence in Mountain and 52.5 percent in Hill and only 37.6 percent were in Terai. But it has rapidly decreased in Mountain and Hill region and reached 6.7 percent and 43 percent and increased in Terai and reached 50.3 percent in 2001.

Table 4: Population Distribution by Development Region(1981 - 2011)

\begin{tabular}{|l|c|c|c|c|c|c|}
\hline $\begin{array}{c}\text { Census } \\
\text { year }\end{array}$ & $\begin{array}{c}\text { Total } \\
\text { population }\end{array}$ & $\begin{array}{c}\text { Eastern } \\
\mathbf{\%}\end{array}$ & $\begin{array}{c}\text { Central } \\
\mathbf{\%}\end{array}$ & $\begin{array}{c}\text { Western } \\
\mathbf{\%}\end{array}$ & $\begin{array}{c}\text { Mid } \\
\text { western } \\
\mathbf{\%}\end{array}$ & $\begin{array}{c}\text { Far western } \\
\%\end{array}$ \\
\hline 1981 & 15022839 & 24.69 & 32.68 & 20.83 & 13.02 & 8.78 \\
\hline 1991 & 18491097 & 24.05 & 33.44 & 20.39 & 13.04 & 9.08 \\
\hline 2001 & 23151423 & 23.09 & 34.69 & 19.74 & 13.01 & 9.47 \\
\hline 2011 & 26494504 & 21.9 & 36.4 & 18.6 & 13.4 & 9.6 \\
\hline
\end{tabular}

Source: CBS 2003 Population monographs V.I, and population monographs 2014, VI, Thapa Navaraj (2015). Population of Nepal, p. 18

As table 4, in all the census year, the highest percent of population are reseeding in central development region, second highest are in eastern development region, third highest are in western development and $4^{\text {th }}$ the highest in mid western development regions and lowest are in far western development regions. 
Table 5: Population Distribution by province ( 2011)

\begin{tabular}{|l|c|c|c|c|}
\hline Province & Population (\%) & Male \% & Female \% & Sex ratio \\
\hline 1 & 17.12 & 47.78 & 52.22 & 91.48 \\
\hline 2 & 20.40 & 50.29 & 49.71 & 101.18 \\
\hline 3 & 20.87 & 49.7 & 50.3 & 98.77 \\
\hline 4 & 9.07 & 45.38 & 54.62 & 83.08 \\
\hline 5 & 16.98 & 47.57 & 52.43 & 90.73 \\
\hline 6 & 5.93 & 48.9 & 51.10 & 95.69 \\
\hline 7 & 9.63 & 47.71 & 52.29 & 91.25 \\
\hline Total & 100.0 & 48.5 & 51.5 & 94.2 \\
\hline
\end{tabular}

NDHS, 2016,

As table 5, highest population are in province No. 3 (20.87\%), second highest in province N0. 2 (20.40\%), third highest in province No.1 (17.12\%), fourth highest are in province No.5, fifth highest are in province No.7 (9.63\%), Sixth highest are in province No. 4 $(9.07 \%)$ and least are in province No. 6 (5.93\%). While analyzed the sex ration by province, highest sex ratio is in province N0. 2 (101.18) and least are in province No. 4 (83.08). The table shows that only province No 2. Have more male than female and rest of 6 provinces have more female than male.

Table 6: Level and Tempo of Urbanization in Nepal (1952/54 - 2017

\begin{tabular}{|l|c|c|}
\hline \multicolumn{1}{|c|}{ Reference years } & Number of urban places & Population in percent \\
\hline $1952 / 54$ & 10 & 2.9 \\
\hline 1961 & 16 & 3.6 \\
\hline 1971 & 16 & 4.0 \\
\hline 1981 & 23 & 6.4 \\
\hline 1991 & 33 & 9.2 \\
\hline 2001 & 58 & 13.9 \\
\hline 2011 & 58 & 17.1 \\
\hline 2014 & 191 & 38.2 \\
\hline 2017 & 293 & 59.0 \\
\hline
\end{tabular}

Sources: CBS, 1993, 2001 and 2011, Population monographs and NDHS 2016

The urban residence populations are gradually increased since 1952/54 to 2011 and then after it has rapidly increased as increased the number of urban areas. As 1952/54 census, there were only 10 municipalities and 2.9 percent population used to stay there. But, in 2017, the urban areas are increased and reached 293 and these urban areas coverage the 59 
percent population (table 6). Presently around 60 percent populations are living in urban area in Nepal.

Table 7: Sex ratio by residence areas 1981 - 2011

\begin{tabular}{|l|c|c|c|c|c|c|c|}
\hline Residencee area & $\mathbf{1 9 5 2 / 5 4}$ & $\mathbf{1 9 6 1}$ & $\mathbf{1 9 7 1}$ & $\mathbf{1 9 8 1}$ & $\mathbf{1 9 9 1}$ & $\mathbf{2 0 0 1}$ & $\mathbf{2 0 1 1}$ \\
\hline Rural & 96.6 & 96.5 & 100.8 & 104.30 & 98.61 & 98.8 & 92.26 \\
\hline Urban & 104.1 & 112.4 & 116.6 & 115.24 & 108.39 & 106.4 & 103.98 \\
\hline Nepal & 96.8 & 97.3 & 101.4 & 105.0 & 99.5 & 99.80 & 94.2 \\
\hline
\end{tabular}

Source: CBS 2014: Population Monograph, vol. II, table 6.3: 227,

As table 7 , the sex ratio are higher in the urban duelers than rural which means male population are more in urban and female population are morerural area. The male population was more comparing to female in 1971 and 1981 then after sex ratio is decreasing continue and reached only 94.2 in 2011.

Table 8: Fertility rate of women 1981-2011

\begin{tabular}{|l|c|c|c|c|c|c|}
\hline \multirow{2}{*}{ Descriptions } & \multicolumn{2}{|c|}{1991} & \multicolumn{2}{c|}{2001} & \multicolumn{2}{c|}{2011} \\
\cline { 2 - 7 } & Urban & Rural & Urban & Rural & Urban & Rural \\
\hline ASFR & 0.679 & 1.07 & 0.563 & 0.873 & 0.333 & 0.542 \\
\hline TFR & 3.40 & 5.35 & 2.82 & 4.37 & 1.67 & 2.71 \\
\hline Nepal & \multicolumn{2}{|c|}{5.16} & \multicolumn{2}{c}{3.8} & \multicolumn{2}{c|}{2.52} \\
\hline
\end{tabular}

Source: CBS 2014, Population Monograph, V.II

Both, ASFR and TFR are high in rural area comparing to urban areas in all census year 1991- 2011 ( table 8).

Table 9: Total Fertility Rate 1996-2016 as NDHS 2016

\begin{tabular}{|c|c|}
\hline Survey year & TFR \\
\hline 1996 & 4.6 \\
\hline 2001 & 4.1 \\
\hline 2006 & 3.1 \\
\hline 2011 & 2.6 \\
\hline 2016 & 2.3 \\
\hline
\end{tabular}

Source: Ministry of Health, NDHS 2016 
Ttotal Fertility Rate (TFR) is a number of children given by individual women during her reproductive period. As table 9, women have given in an average 5 children during her reproductive age (15-49 years) in 1996, and around 4 children in 2001, quite more than 3 children in 2006, around 3 children in 2011 and slightly more than 2 children given in 2016 . The trends of TFR is decreasing gradually.

Table 10: CBR and CDR trend 1981-2011

\begin{tabular}{|l|c|c|}
\hline Reference year & CBR & CDR \\
\hline 1981 & 39.7 & 13.5 \\
\hline 1991 & 39 & 13.3 \\
\hline 2001 & 33.3 & 10.3 \\
\hline 2011 & 22.4 & 7.3 \\
\hline
\end{tabular}

Source: CBS 2011, Population Monograph V. II

Crude Birth Rate (CBR) is number of birth within a year in 1000 people. Like wise Crude Death Rate (CDR) is number of crude death within a year in 1000 people. Both CBR and CDR are gradually decreasing since 1981 to 2011. CBR was almost 40 in 1000 people in 1981 and 39 in 1991, 33.3 was in 2001 and 22.4 in 2011. Likewise, CDR was almost 14 in 1000 in 1981, and it has slightly decreased and reached 13.3/1000 in 1991, 10.3 in 2001 and 7.3 in 2011. It seems that the natural population growth rate is still high (table 10)

Table 11: Life Expectancy by gender in years

\begin{tabular}{|l|c|c|c|c|c|c|c|c|}
\hline \multicolumn{1}{|c|}{ Gender } & $\mathbf{1 9 7 4 / 7 5}$ & $\mathbf{1 9 6 1}$ & $\mathbf{1 8 7 1}$ & $\mathbf{1 9 8 1}$ & $\mathbf{1 9 9 1}$ & $\mathbf{2 0 0 1}$ & $\mathbf{2 0 1 1}$ & $\mathbf{2 0 1 8}$ \\
\hline Male & 27.1 & 35.2 & 42.1 & 50.9 & 55.0 & 60.0 & 65.5 & 70 \\
\hline Female & 28.5 & 37.4 & 40.0 & 48.1 & 53.5 & 61.5 & 67.9 & 71 \\
\hline Both & - & - & - & - & - & 61.0 & 66.6 & 69 \\
\hline
\end{tabular}

Source: CBS 2014, Population monographs, PRB 2018, World Population data sheet, CBS 2003, Population monographs,

Life expectancy is major indicators of overall development of the country. Nepal, life expectancy was only 27.1 years of male and 28.5 year of female in 1952/54 and after the life expectancy of people is gradually increasing as increased the socio, economic and health facilities of the people. As PRB 2018, the life expectancy of Nepalese people reached 70 years of male and 71 years of female (table 11) 
Table 12: Old Aged Population InNepal (60 years and above)

\begin{tabular}{|l|c|c|}
\hline Censuses & Male & Female \\
\hline $1952 / 54$ & 4.5 & 5.4 \\
\hline 1961 & 4.8 & 5.6 \\
\hline 1971 & 5.3 & 5.9 \\
\hline 1981 & 5.9 & 5.5 \\
\hline 1991 & 5.9 & 5.7 \\
\hline 2001 & 6.4 & 6.3 \\
\hline 2011 & 6.8 & 7.1 \\
\hline
\end{tabular}

Source: CBS 2014, Population monograph, V.II

As International definition, 65 years and above aged population are called the old aged population. But in Nepal case, 60 years and above population are called the old aged population. While analyze the status of old aged population in Nepal, only 4.5 male and 5.4 percent female were aged 60 years and above in 1952/54 and this rate is gradually increasing and reached 6.8 percent male and 7.1 percent female in 2011(table 12). The old age population growth rate is higher than national population growth rate $3.3 \% \mathrm{v} .1 .35 \%$. Therefore, number of old age population will be large in near future.

Table 13: Literacy rate of 6 years and above by gender in Nepal (1981- 2011

\begin{tabular}{|l|c|c|c|c|}
\hline Gender & $\mathbf{1 9 8 1}$ & $\mathbf{1 9 9 1}$ & $\mathbf{2 0 0 1}$ & $\mathbf{2 0 1 1}$ \\
\hline Male & 34.0 & 54.5 & 65.5 & 75.13 \\
\hline Female & 12.0 & 25.0 & 42.8 & 57.38 \\
\hline Both & 23.3 & 39.6 & 54.1 & 65.94 \\
\hline
\end{tabular}

Source: CBS, population Monographs 2014 vol.II and 2003 v. I, p 239

Literacy is one of the indicators of human development. It show the level of knowledge of human population and level of development of the country. There was only 23.3 percent people were literate in 1981, among of them female literacy rate was almost two third less. But it has gradually increasing and reached 65.94 percent people literate in 2011. There is still gap between male and female literacy rate but not much bigger gap like 1981 (table 13) 
Patan Pragya (Volume: 7 Number: 1 2020)

Table 14: Percent of Population by Religions In Nepal, 19961-2011

\begin{tabular}{|l|c|c|c|c|c|c|c|}
\hline Religion & $\mathbf{1 9 5 2 / 5 4}$ & $\mathbf{1 9 6 1}$ & $\mathbf{1 9 7 1}$ & $\mathbf{1 9 8 1}$ & $\mathbf{1 9 9 1}$ & $\mathbf{2 0 0 1}$ & $\mathbf{2 0 1 1}$ \\
\hline Hindu & 88.9 & 87.7 & 89.5 & 89.5 & 86.5 & 80.6 & 81.3 \\
\hline Buddhist & 8.6 & 9.3 & 7.5 & 5.3 & 7.8 & 10.7 & 9.9 \\
\hline Islam & 2.5 & 3.0 & 3.0 & 2.7 & 3.5 & 4.2 & 4.4 \\
\hline Kirat & - & 0.0 & 0.0 & 0.0 & 1.7 & 3.6 & 3.0 \\
\hline Jain & - & 0.0 & 0.0 & 0.0 & 0.0 & 0.0 & 0.0 \\
\hline Christian & - & 0.0 & 0.0 & 0.0 & 0.2 & 0.4 & 1.4 \\
\hline Others & - & 0.0 & 0.0 & 0.5 & 0.3 & 0.1 & 0.0 \\
\hline
\end{tabular}

Source: Population of Nepal, 2015, p. 66

In Nepal, still leading by Hindu religion.It was almost 89 percent in 1952/54 but gradually decreasing and reached 81.3 percent in 2011. But percent of Buddhism are fluctuation. But other religionists are increasing gradually (table 14.) Now, new religionists are emergingi.e Christianity, Bahai and manyothers.

Table 15: Population distribution by mother tongue (1991- 2011

\begin{tabular}{|l|c|c|c|}
\hline Mother tongue & $\mathbf{1 9 9 1}$ & $\mathbf{2 0 0 1}$ & $\mathbf{2 0 1 1}$ \\
\hline Nepali & 50.3 & 48.6 & 44.6 \\
\hline Maithali & 11.9 & 12.3 & 11.7 \\
\hline Bhojpuri & 7.5 & 7.5 & 6.0 \\
\hline Tharu & 5.4 & 5.9 & 5.8 \\
\hline Tamang & 4.9 & 5.2 & 5.1 \\
\hline Newar & 3.7 & 3.6 & 3.2 \\
\hline Magar & 2.3 & 3.4 & 3.0 \\
\hline Limbu & 1.4 & 1.5 & 1.3 \\
\hline Gurung & 1.2 & 1.5 & 1.2 \\
\hline Rai & 2.4 & na & 0.6 \\
\hline Others & & & \\
\hline
\end{tabular}

Source: Population of Nepal, 2015, pp76-77

As table 15, more than 50 percent people used to speak Nepali language in 1991, and it was decreased and reached 48.6 percent in 2001 and 44.6 percent in 2011. The percent of Nepalese speakers are gradually decreasing. Maithali speakers are fluctuating. Bhojpuri speakers are constrain in 1991 and 2001 but decreased and reached in 6 percent in 2011. But other speakers are increasing i.e Tharu speakers, Tamang speakers. 
Patan Pragya (Volume: 7 Number: 1 2020)

Table 16: Population Distribution by Dependency Ratio 1952/54 - 2011

\begin{tabular}{|l|c|c|c|}
\hline Census year & $\begin{array}{c}\text { Child dependency } \\
\text { rate }\end{array}$ & Old age dependency rate & $\begin{array}{c}\text { Overal dependency } \\
\text { rate }\end{array}$ \\
\hline 1952.54 & 68.5 & 8.9 & 77.4 \\
\hline 1961 & 73.0 & 9.5 & 82.6 \\
\hline 1971 & 75.0 & 10.4 & 85.4 \\
\hline 1981 & 78.1 & 10.8 & 88.9 \\
\hline 1991 & 81.9 & 11.2 & 93.1 \\
\hline 2001 & 72.7 & 12.0 & 84.7 \\
\hline 2011 & 61.3 & 14.3 & 75.6 \\
\hline
\end{tabular}

Source: Population of Nepal 2015, p. 47

There are two types of dependency ratio in population by age, one is child dependency ratio and another is old age dependency ratio. There was 77.4 people were dependent in 100 active age population in 1952/54 and among of them 68.5 were child dependency and 8.9 were old age dependency. Both child and old age dependency ratio were increased until1991 and after than, child dependency ratio is gradually decreasing and old age dependency are still increasing. As 2011 census child dependency ratio was 61.3 and old age dependency ratio was 14.3 (table 16)

Table 17: Caste/ethnic Groups Identification, 1991-2011

\begin{tabular}{|l|c|}
\hline Census year & number of caste/ethnic group identified \\
\hline 1991 & 60 \\
\hline 2001 & 100 \\
\hline 2011 & 125 \\
\hline
\end{tabular}

Source: Population of Nepal, 2015

The identified of the caste ethnic groups are increasing as increasing the development, freedom and rights of people and especially reasons is that the government provision of reservation in all sectors for all on the basis of theircaste/ethnic groups.There were only 60 caste/ethnic groups were identified in 1991, and it has increased and reached 100 caste/ethnic groups in 2001 and 125 caste/ethnics groups in 2011 (table 17). This tendency will be continue until next few years. 
Patan Pragya (Volume: 7 Number: 1 2020)

Table 18: Top Ten Cast/ethnic Group 1991-2011

\begin{tabular}{|l|c|c|c|}
\hline Caste ethnic groups & $\mathbf{1 9 9 1} \%$ & $\mathbf{2 0 0 1} \%$ & $\mathbf{2 0 1 1} \%$ \\
\hline Chhetri & 16.05 & 15.8 & 16.6 \\
\hline Brahmin & 12.92 & 12.7 & 12.2 \\
\hline Magar & 7.24 & 7.1 & 7.1 \\
\hline Tharu & 6.46 & 6.8 & 6.6 \\
\hline Tamanag & 5.51 & 5.6 & 5.8 \\
\hline Newar & 5.63 & 5.5 & 5.0 \\
\hline Musalman & 3.53 & 4.3 & 4.4 \\
\hline Kami & 5.21 & 3.9 & 4.8 \\
\hline Yadhav & 4.13 & 3.9 & 4.0 \\
\hline Rai & 2.84 & 2.8 & 2.3 \\
\hline
\end{tabular}

Source: Thapa N. 2015, Population of Nepal

While analyzed the status of caste/ethnic groups, there are Chhetri, Brahmin, Magar, Tharu, Tamang, Newar, musalman, Kami, Yadhav, Rai are in top 10 caste/ethnic groups. Among of them highest percent are Chhetri, second are Brahmin, third highest are Magar, fourth highest are Tharu, fifth highest are Tamang, sixth highest are Newar, seventh highest are Musalman, eight highest are Kami, ninth highest are Yadhav and tenth highest are Rai in all census years 1991, 2001 and 2011 respectively ( table 18)

Table 19 : Percent of Mother Tongue Language Speakers (1991-2011)

\begin{tabular}{|c|c|c|c|}
\hline $\begin{array}{c}\text { Mother tongue } \\
\text { speakers }\end{array}$ & $\begin{array}{l}1991 \\
(\%)\end{array}$ & $\begin{array}{l}2001 \\
(\%)\end{array}$ & $\begin{array}{l}2011 \\
(\%)\end{array}$ \\
\hline Nepali & 50.3 & 48.6 & 44.6 \\
\hline Maithali & 11.6 & 12.3 & 11.7 \\
\hline Bhojpuri & 7.5 & 7.5 & 6.0 \\
\hline Tharu & 5.4 & 5.9 & 5.8 \\
\hline Tamang & 4.9 & 5.2 & 5.1 \\
\hline Newari & 3.7 & 2.6 & 3.2 \\
\hline Rai/Kiranti & 3.4 & 2.3 & - \\
\hline Magar & 2.3 & 3.4 & 3.0 \\
\hline Awadhi & 2.0 & 2.5 & Bajika \\
\hline Limbu & 1.4 & 1.5 & Doteli \\
\hline Gurung & 1.2 & 1.5 & Urdu \\
\hline
\end{tabular}

Source: Thapa N. 2015, Population of Nepal, p. 75 
While analyzed the mother tongue language speakers, Nepali, Maithali, Bhojpuri, Tharu, Tamang, Newari, Rai/Kiranti, Magar, Awadhi, Limbu and Gurung are in top ten. First highest are Nepali, second highest are Maithali, third highest are Bhojpuri, fourth highest are Tharu, fifth highest are Tamang, sixth highest are Newari, seventh highest are Rai/Kiranti and eight highest are Magar in all census 1991, 2001 but slightly changed in 2011. There Bajika, Doteli and Urdu speakers in eight, nine and tenth position in 2011 (table 19)

Table 20.Economically Active Population Rate by Gender (Age 10 years and above) $1981-2011$

\begin{tabular}{|l|c|c|c|c|}
\hline \multicolumn{1}{|c|}{ Gender } & $\mathbf{1 9 8 1}$ & $\mathbf{1 9 9 1}$ & $\mathbf{2 0 0 1}$ & $\mathbf{2 0 1 1}$ \\
\hline Male & 83.2 & 68.2 & 71.7 & 62.5 \\
\hline Female & 46.2 & 45.2 & 55.3 & 46.8 \\
\hline Both & 65.1 & 56.6 & 63.4 & 57.2 \\
\hline
\end{tabular}

Source: CBS 2014: Population monograph, V.II, p 251

While analyzing the economically active population aged 10-59 years of 4 presiding census years (2081 -2011), the male economically active population is higher comparing to female. As table 20, in total 65.1 percent economically active population in 1981 and among the male 83.2 percent was economically active and among the female, 46.2 percent were economically active. The economically active population rates are fluctuation in both male and female 1991 - 2011.

\section{Conclusion}

Number of population are almost 5 fold increased during the $(1930$ - 2011) 80 years period of time. The population growth rate and doubling times are fluctuation. CDR, CBR, IMR, CMR, MMR are decreasing as increasing of the socio economic development. Life expectancy, literacy rate, active age population rate are increasing. The identification of the caste/ethnic groups are rapidly increasing, only 60 caste/ethnic group were identified in 1991, it has increased and reached 100 caste/ethnic groups in 2001 and 125 caste/ethnic groups in 2011 census. Population dependency ratio of child is decreasing and increasing the old age dependency ratio. If old age population growth rate will remaining the same the old age dependency ratio will be increased by 3 fold till 2050. However, Nepal is almost enter into the ageingnation. Active age population will be increase till more few years after then it will be decreases gradually. Presently, around 60 percent people are living in urban duelers so population growth rate will more decrease in future days. However, 2078 census is expecting total population to be more than 31.5 millions. If so, the Nepal population will be 6 fold increases within the 110 years period of time. 


\section{References}

CBS,.(2003).Population Monograph, V.1, National Planning Commission Secretariat. Ramshahpath, Kathmandu.

CBS,.(2011). National population and Housing Census 2011: National Report, National Planning Commission, Ramshahpath, Kathmandu.

CBS,.(2014).Population Monograph, V.II, National Planning Commission Secretariat.

Ramshapath, Kathmandu

CBS,.(1993). Population Monographs, V.I, National Planning Commission, Secretariat, Ramshahpath, Kathmandu.

CBS,.(2011). Nepal Living Standard Survey 2010/11, V I., p22. National Planning Commission, Secretariat, Ramshahpath, Kathmandu.

Ghimire D. (2001).Women's Political Participation and Challenges.Gender and Democracy in Nepal.Center Department of Home Science Women's Studies Program, Tribhuvan University.

Government of Nepal, (2016) Nepal Demographic and Health Survey. Ministry of Health,

New ERA; and ICF, Kathmandu, Nepal.

Government of Nepal, (2017). Parliamentary Council Member election 2017: Election

Result Book, First Inclusive Election System. Election Commission of Nepal. Kantipath, Kathmandu.

Government of Nepal, (2017). Province Council member election 2017: Election Result

Book, First Inclusive Election System. Election Commission of Nepal. Kantipath, Kathmandu.

PRB., ( 2018). World Population Data Sheet.www.prb.org,

Regmi, K,, (2013). Status of Women in Nepal. Journal of Midwifery and Women'sHealth.https://www.ncbi.nlm.nih.gov/pmc/articles.

Sakya, K., (2014). Changing Gender Status: Achievements and Challenges. Population Monograph,

Shrestha, S.L, (1994). Gender Sensitive Planning What, Why and How in Nepal. Women Awareness Center Nepal. Office Support Service Center Press, Kathmandu.

Thapa N. (2015). Population of Nepal. Vidhyarthi Pustak Bhandar. Bhotahiti, Kathmandu, Nepal

UNESCO, (2003).Baseline Definitions of Key Concepts and Terms of Gender Empowerment, UNESCO Head Office, Geneva. 